\title{
The Attributes of Dysfunctional Audit Behavior (DAB): Second Order Confirmatory Factor Analysis
}

\author{
M. Ardiansyah Syam ${ }^{1}$, Syahril Djaddang ${ }^{1}$, Mulyadi $^{1} \&$ Imam Ghozali $^{2}$ \\ ${ }^{1}$ Faculty of Economics, Pancasila University, Indonesia \\ ${ }^{2}$ Faculty of Business and Economics, Diponegoro University, Indonesia \\ Correspondence: Imam Ghozali, Faculty of Business and Economics, Diponegoro University, Indonesia
}

Received: October 11, 2019

Accepted: December 23, 2019

Online Published: March 17, 2020

doi:10.5430/ijfr.v11n2p311

URL: https://doi.org/10.5430/ijfr.v11n2p311

\begin{abstract}
This paper is intended to confirm the attributes of dysfunctional audit behavior (DAB). The attributes of dysfunctional audit behavior consist of under-reporting of time (URT), premature sign-off (PMSO), and time-budget pressure (TBP). We propose task complexity as a new attribute of dysfunctional audit behavior. The data was gathered from 367 senior auditors who work at Big-fourand Non-big four of 140 Public Accounting Firms that registered in Indonesian Public Accounting Association (IAPI). The data was processed using Second Order Confirmatory Factor Analysis (SEM-PLS) - SmartPLS3. The result of the study confirmed that the attributes of under-reporting of time (URT), positively, manifest the dysfunctional audit behavior. The attributes of premature-sign-off (PMSO), positively, manifest the dysfunctional audit behavior. The attributes of time-budget pressure (TBP), positively, manifest the dysfunctional audit behavior. The proposed factor, task complexity (TC) positively, manifests the dysfunctional audit behavior. The premature-sign-off is the most dominant factor reflecting/manifesting the dysfunctional audit behavior. The under-reporting of time (URT), premature sign-off (PMSO), time-budget pressure (TBP), and task complexity (TC) can be used as the predictor of dysfunctional auditor behavior (DAB). The higher the incidence of their attributes, the higher the potential incidence of dysfunctional audit behavior is.
\end{abstract}

Keywords: Dysfunctional Audit Behavior (DAB), Under-reporting of Time (URT), Premature Sign-Off (PMSO), Time-Budget Pressure (TBP), Task Complexity (TC)

\section{Introduction}

Dysfunctional audit behavior (DAB) is a set of actions or behaviors that reduce the audit quality (Paino, 2010, 2012, 2014; Pruijssers, et.al 2013; Grace, 2016). In Indonesia, there are so many violations committed by public accountants. Audit violations, in general, are related to non-compliance of auditors to the applicable auditing standards and professional codes of conduct (Ardelean, 2013; Amrizal, 2014: Al-Shbiel, 2016; Armitage and Moriarity, 2016).

Auditor competence and independence are very influential on the performance of auditors (Alissa, et al 2014, Abbot, et al 2016). In addition to non-compliance with audit standards, violations also relate to dysfunctional audit behavior from audit processes and procedures (Otley and Dias, 1982); Otley and Bernard (1995; Paino 2010, 2011, 2012, 2014; Amroabadi, et al 2014). Dysfunctional audit behavior is due to low comprehension and auditor compliance to Auditing Standards, Financial Accounting Standards and Professional Accounting Standards (Amrizal, 2014: Al-Sbiel, 2016; Armitage and Moriarity, 2016). Novatiani (2014) explains that the manipulation of working papers is a problem faced by many public accountants.

The research's phenomena on antecedents of dysfunctional audit behavior needs to be done, especially concerning in auditor and auditing task (Ponemon, 1992; Paino, et al 2011; Binti Adnan, et al 2012; Ariantini, et al , 2014, Chadegani, et al 2015, Baldaccino, et al 2016). The facts show that auditors often behave in a deviant manner in carrying out auditing assignments. The deviant behavior in the implementation of the audit is any action performed by auditors in conducting audits that reduce the quality of audits (Kelley and Margheim, 1990; Paino, et al. 2011; Ariantini, et al, 2014, Baldaccino, et al 2016). 
The irregular auditing practices are dysfunctional audit behavior that reduce or threat to the audit quality (Kelley and Margheim, 1990; Otley and Pierce, 1996; Nazli, 2009; Paino, et al 2010, 2014; Beekes, et al 2014 ). The actions performed by the auditor that reduce the quality of the audit are directly referred to as audit quality reduction behaviors, while the indirect actions that reduce the quality of the audit are called underreporting of time (Kelley and Margheim, 1990; Otley and Pierce, 1996; Gundry, 2006; Basuki and Yunika, 2010; Paino, 2012). Nehme (2016) found that the time budget pressures faced by external auditors affect the dysfunctional audit behavior.

Besides under-reporting of time, the premature sign-off threat to the quality of the audit because the audit evidence and procedures collected during the audit were insufficient as an adequate basis for the auditor to express an opinion on the fairness of the audited financial statements (Alderman and Deitrick, 1982; Kelley and Margheim, 1990; Otley and Pierce, 1995; Otley and Pierce, 1996; Coram, et al 2003; Nazli, 2009). Nehme (2016) examines the importance of auditor performance evaluation to ensure quality audit results.

The dysfunctional audit behavior is often carried out through various actions, such as early discontinuation of audit procedures, superficial review of client documents, not investigating the suitability of the client's accounting treatment, acceptance of inadequate client explanations, reducing audit procedures, and expanding audit scope when detected or found in dubious posts (Kelley and Margheim, 1990; Otley and Pierce, 1996; Sea, 2011, Paino, et al 2014; Khan, et al 2013). Kustinah (2013) examines the linkage between dysfunctional audit behavior and auditor ethics towards audit quality. Anugerah et al (2016) stated that the auditor's probability of issuing wrong opinions is higher when auditors perform audit quality reduction behavior during the audit implementation.

Time-budget pressures cause the auditor to be depressed and may lead to practice the dysfunctional audit behavior (Cook and Kelly, 1988; Gundry, 2006; Halim, et al 2014; Svanstrom, 2016). Auditor attitudes that accept audit dysfunctional audit behavior may indicate the level of auditor's independency and competency (Halim, et al 2014, Gray and Irons, 2016). The dysfunctional audit behavior is performed through data manipulation or evidence, fraud, and deviations from applicable audit standards. This may affect the audit results, either directly or indirectly (Sweene and Pierce, 2015). The dysfunctional audit behavior can be characterized by several behaviors, namely premature sign-off and altering or replacing audit procedures that lead to lack of gathered evidence (gathering insufficient evidence), inaccurate audit implementation and procedures. In addition, underreporting of time (URT) can also be the cause of time pressures in the subsequent audit process (Paino, 2011, 2014; Khan, et al 2015, Syam, et al 2017).

Task complexity is one of the important factors that must be explicitly considered in investigating the effect of years of service on the dysfunctional audit behavior. Jiambalvo and Prat (1982) stated that the task complexity is related to the level of innovation, audit judgment required by the auditor in completing the audit assignment. Asare and McDaniel (1996) examined the relationship between the task complexity and the effectiveness of the audit review. Sanusi, et al (2007) examined the effect of task orientation and task complexity on audit judgment. Liu and Li (2012) review and formulate a conceptualized conceptual framework.

The underlying assertion of many academic researches revealed that dysfunctional audit behavior is merely a reaction to the environment. The dysfunctional audit behavior may have both direct and indirect impacts on audit quality. Manners that directly affect audit quality comprise premature sign-off. Underreporting of time has also been demonstrated to hold indirect impact on audit quality. Underreporting of time and time-budget pressure had same indirect effect on audit quality. Besides task complexity also had a same effect of audit quality.

This research focuses on the manifestation of attributes of dysfunctional audit behavior (DAB). The attributes of dysfunctional audit behavior consist of: under-reporting of time (URT), premature sign-off (PMSO), and time-budget pressure (TBP). We propose task complexity as a new attribute of dysfunctional audit behavior. First, we test the significance of the outer loading of all attributes in reflecting/manifesting Under-reporting of Time (URT); Premature Sign-off (PMSO); Time-Budget Pressure (TBP); Task Complexity (TC). Secondly, we test the significance of the factors in reflecting/manifesting the dysfunctional audit behavior.

\section{Literature Review}

\subsection{Dysfunctional Audit Behavior}

Dysfunctional auditor behavior (DAB) is defined as certain actions of auditors that allow for the opportunity for a substandard audit (Donnelly et al., 2003). It is also referred to as reduced audit quality behavior (Coram et al., 2003), reduced audit quality practices (RAQP), (Malone and Roberts, 1996). These dysfunctional audit behaviors have been summarized by Gundry (2006) as comprising the actions of prematurely signing off an audit program steps. It is defined as making a superficial review of client's documents and failing to adopt the accounting principle properly. It is also be seen as a failing to pursue a questionable item in the audit and rejecting an awkward item in a sample 
and accepting weak client explanations. The consequence of DAB is the audit process fails to accumulate adequate and reliable audit evidence. It could lead to an ineffective audit as the auditor may reach a wrong conclusion without adequate and reliable audit evidence. Previous studies have documented the types and extent to which dysfunctional auditor behaviors among auditors at various levels Herrbach (2001), Coram et al. (2003), Gundry (2006) and Paino et al. (2011). Nazli et al. (2010) found that, in Malaysia, more than 70\% of surveyed auditors committed at least once dysfunctional auditor behaviors acts throughout their career.

\subsection{Under-Reporting Time (URT)}

Underreporting of time, is reporting fewer hours than actually worked, is a prevalent behavior among auditors at all levels. Underreporting of time gives a negative consequence such as tight budgets and reductions in future audit quality. Underreporting time is a common ethical dilemma among auditors and has several detrimental consequences for public accounting firm (Pickerd et.al, 2015). Under-reporting of audit time has also been shown to have an indirect impact on audit quality (Smith 1995; Kelley and Margheim 1990; Lightner et al. 1982; Ponemon, 1992).

Under-reporting of time is a common ethical dilemma among auditors and has several detrimental consequences for public accounting firms (Pickerd, et al 2015). Underreporting of time is ubiquitous in public accounting firms (Church 2014; Pickerd et.al, 2015). Given the negative effects of underreporting on audit firms and the profession, it is important to consider factors that may influence auditors' acceptance of time and budget pressure. Several academic studies have also examined the impact that time pressure on dysfunctional audit behavior (Margheim and Pany 1986; Alderman and Deitrick 1978, 1982). Kelley and Margheim (1990) tested the moderating effects of the interaction between supervisor leadership style and auditor personality. Otley and Pierce (1995) extend this work by examining the moderating effects of audit manager's leadership style on the behavior of senior auditors. These studies suggest that an optimal supervisor-subordinate can reduce dysfunctional reactions to control systems.

\subsection{Premature Sign-Off (PMSO)}

A premature audit sign-off occurs when an auditor documents the completion of a required procedure that is not covered by other audit procedures, without performing the work or noting the omission of the procedure. Otley and Pierce (1996) define premature sign-off as the act of declaring that the required audit process and procedures were performed, but it was not performed completely or omitting the procedure altogether. The previous research, Rhode (1977) found that almost 60 percent of the respondents had prematurely signed-off on a required audit procedure some time during their career. Because he excluded first and second year auditors and non-CPAs from his survey, it is possible that Rhode may have understated the magnitude of premature sign-off activities. Alderman and Deitrick (1982) conducted the follow-up study, which included auditors with less than two years of experience. Alderman and Deitrick (1982) found that the incidence of premature sign-off to be more widespread than what was found by Rhode (1977).

\subsection{Time-Budget Pressure (TBP)}

The ability to meet budgeted time has been considered a very important factor in evaluating performance and affecting promotion prospects of auditors (Otley and Pierce, 1996; Soobaroyen and Chengabroyan, 2006). The previous studies showed that the time-budget pressure has been increasing over time during the tight competition. Otley and Pierce (1996) found the relation between pressures created by audit control systems and dysfunctional audit behavior. They proofed that the contextual variable, auditor with limited time and budget, tend to perform dysfunctional audit behavior. The auditing is a business and the audit business has been facing sustained audit fee pressures (time-budget pressures). The audit firm, therefore, has to be tightly controlled to ensure that time and budget (resources) are adequate to meet the required audit task.

The behaviors that directly affect audit quality include premature signing-off of audit steps without completion of the procedure (Rhode 1978; Alderman and Deitrick 1978; Otley and Pierce 1995), gathering of insufficient evidential materials (Alderman and Deitrick 1982), processing inaccuracy (McDaniel 1990), and the omission of audit steps (Margheim and Pany 1986).

\subsection{Task Complexity (TC)}

The failure itself not only because of the difficulties in auditing the complexity of estimation and accounting numbers, but there are other things that add to the problem (Yuen, 2012), namely the complexity of the task. Davies et al. (1994) demonstrated through experiments based on information that seems too confident in the information used to produce the estimations. The complexity of audit work can also affect the possibility of the auditors engaged in adverse behaviors. 


\subsection{Conceptual Framework and Hypothesis}

This study is intended to confirm the attributes of dysfunctional audit behavior (DAB). The attributes of dysfunctional audit behavior consist of: under-reporting of time (URT), premature sign-off (PMSO), and time-budget pressure (TBP). We propose task complexity as a new attribute of dysfunctional audit behavior. The conceptual framework as shown in the Figure 1.

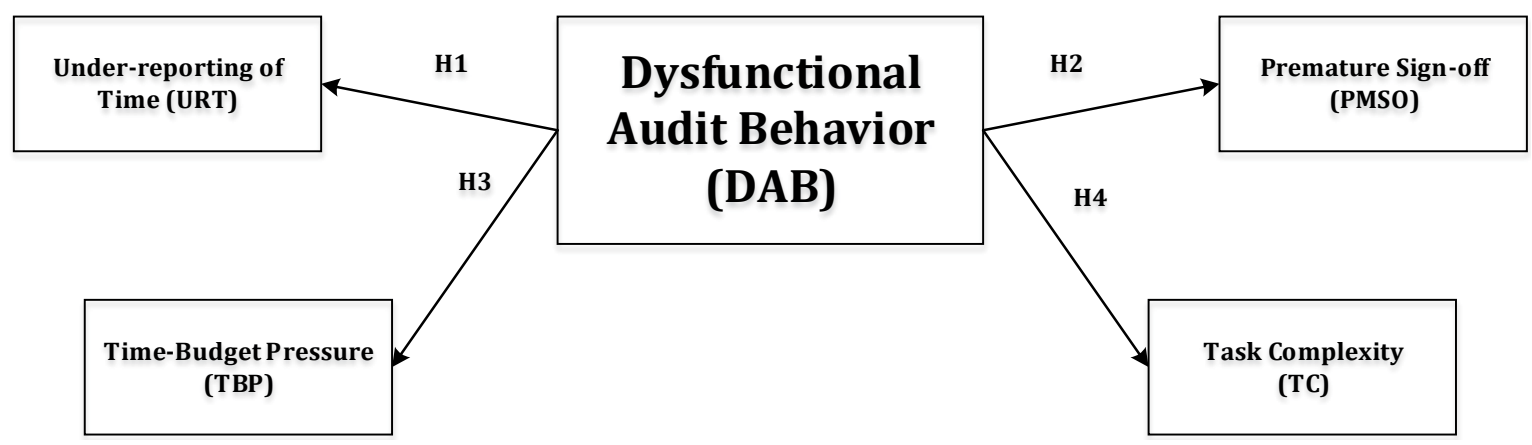

Figure 1. Conceptual framework

Based on the conceptual framework, the hypotheses of this research are defined as follows:

Hypothesis 1: The attributes of under-reporting of time (URT) positively manifest the dysfunctional audit behavior (DAB).

Hypothesis 2: The attributes of premature sign-off (PMSO) positively manifest the dysfunctional audit behavior (DAB).

Hypothesis 3: The attributes of time-budget pressure (TBP) positively manifest the dysfunctional audit behavior (DAB).

Hypothesis 4: The attributes of task complexity (TC) positively manifest the dysfunctional audit behavior (DAB).

\section{Methodology}

The data was gathered from 367 senior auditors who work at Big-four and Non-big four of 140 Public Accounting Firms that registered in Indonesian Public Accounting Association (IAPI). Questionnaires were sent to 480 respondents and 420 returned the questionnaire. There were 367 questionnaires were fulfilled and used for the analysis. The attributes of Under-reporting of Time (URT); Premature Sign-off (PMSO); Time-Budget Pressure (TBP); Task Complexity (TC) are defined and shown in the table below:

Table 1. The attributes of Dysfunctional Audit Behavior (DAB)

\begin{tabular}{|c|c|}
\hline Construct & Indicators/Attributes \\
\hline \multirow[t]{6}{*}{$\begin{array}{l}\text { Under-reporting of } \\
\text { Time (URT) }\end{array}$} & $\begin{array}{l}\text { 1. The auditor does not charge all the time that should be used to complete the audit } \\
\text { work }\end{array}$ \\
\hline & 2. Auditor works with personal time. \\
\hline & 3. Auditor works harder but charges all the time correctly. \\
\hline & 4. Auditor requests and get increased budget time and expense. \\
\hline & $\begin{array}{l}\text { 5. Auditor divides (allocates) time to time that should not be used to complete the } \\
\text { audit work. }\end{array}$ \\
\hline & 6. Auditor divides(allocates) time to different clients. \\
\hline \multirow{3}{*}{$\begin{array}{l}\text { Premature Sign-off } \\
\text { (PMSO) }\end{array}$} & 1. The auditor does not need understanding a client's business. \\
\hline & 2. Auditor does not use internal control considerations in financial statement audits? \\
\hline & 3. The auditor does not consider the internal auditor's function in auditing financial \\
\hline
\end{tabular}


statements?

4. The auditor does not use assertion information in formulating audit objectives and in designing substantive tests?

5. The auditor does not use analytical procedures in the planning stages and the final audit review stage?

6. The auditor does not confirm in financial statement audit?

7. Auditor does not use management representation in financial state-ment audit?

8. The auditor does not perform compliance testing of control over transaction within the on-line computer system application?

9. The auditor reduces the number of samples that have been planned in the financial statement audit?

10. The auditor does not perform physical calculations of cash or inventory at hand?

Time-Budget 1. Auditor accepts the accelerated completion of the audit, without asking the Pressure (TBP) supervisor's advice.

2. The auditor accepts the accelerated completion of audit time if it improves my performance evaluation appraisal.

3. The auditor accepts an accelerated settlement of audit time if it allows me to promote promotion.

4. The auditor accepts termination of some audit steps without changing any other audit procedures if the auditor believes the audit step is not necessary.

Task Complexity 1. Generally, the procedures required to complete the audit sections assigned to me (TC) have been well formulated.

2. Generally, the audit approach helps me in completing each audit assignment.

3. Generally, it is easy and simple to determine the accuracy of the procedures used to complete the audit sections assigned to me.

4. Generally, some judgment, audits are needed to determine when sufficient evidence has been collected to give consideration to whether the audit sections are sufficient to complete.

5. Overall the tasks performed are relatively simple or easy and do not require innovation or judgment/audit considerations.

All of the attributes of Under-reporting of Time (URT); Premature Sign-off (PMSO); Time-Budget Pressure (TBP); Task Complexity (TC) were measured using 5 points Likert scale.

\section{Data Analysis and Interpretation}

The Second Order Confirmatory Factor Analysis (Second Order CFA) was used to test the proposed hypotheses. First, we test the significance of the outer loading of all attributes in reflecting/manifesting Under-reporting of Time (URT); Premature Sign-off (PMSO); Time-Budget Pressure (TBP); Task Complexity (TC). Secondly, we test the significance of the factors in reflecting/manifesting the dysfunctional audit behavior.

The running of PLS analysis involves two-step procedures. The first step is to evaluate a measurement model for each latent construct or to assess the validity and reliability of the measures. The second step is to conduct a second order confirmatory factor analysis. Chin, Marcolin and Newsted (2003) advise that the adequacy of the measures is assessed by evaluating three components; first, the reliability of the individual items, second, the internal consistency of the items measuring the same latent construct, and third, the discriminant validity of the construct. The reliability of the individual items is assessed by examining the loading factors of the items on their corresponding construct. 




Figure 2. Second order confirmatory factor analysis of attributes reflecting/manifesting Dysfunctional Audit Behaviors

The reliability is indicated by Cronbach Alpha. The internal consistency is assessed by Composite reliability (CR) with the desired value of above 0.7. The average variance extracted (AVE) simply refers to how much the items explain the variance of the construct. The desired value for AVE is above 0.5 .

Table 2. Reliability, internal consistency, and average variance extracted

\begin{tabular}{lllll}
\hline & AVE & R Square & Cronbach Alpha & Composite Reliability \\
\hline Dysfunctional Audit Behavior (DAB) & 0.801 & & 0.917 & 0.941 \\
\hline Under-reporting of Time (URT) & 0.553 & 0.818 & 0.888 & 0.881 \\
\hline Premature Sign-off (PMSO) & 0.502 & 0.866 & 0.839 & 0.909 \\
\hline Time-Budget Pressure (TBP) & 0.668 & 0.772 & 0.834 & 0.889 \\
\hline Task Complexity (TC) & 0.634 & 0.787 & 0.850 & 0.895 \\
\hline
\end{tabular}

\subsection{The Attributes of Dysfunctional Audit Behavior - First Order Confirmatory Factor Analysis}

\subsubsection{The Attributes of Under-Reporting of Time (URT)}

Statistically, an attribute or indicator has reflective ability to proxy the latent variable (indicate the respective construct) as stated in loading factor. The indicator is significant if the $\mathrm{t}_{\text {-statistic }}$ is above 1.96 , and the $\mathrm{p}_{\text {-value }}$ is lower than 0.05. Based on the table, all of the indicators have $t_{\text {-statistic }}$ higher than 1.96. It means that there was no misspecification of the usage of indicators/attributes in building a construct.

To test the significance of attribute in reflecting/manifesting the latent variables, the $\mathrm{t}_{\text {-statistic }}$ must be higher than 1.96 and probability ( $\mathrm{p}$-values $)$ must be lower than 0.005 . The $\mathrm{t}_{\text {-statistic }}$ or $\mathrm{t}_{\text {-value }}$ of the attributes under-reporting of time (URT) are shown in the table. 
Table 3. The manifestation of attributes of Under-Reporting of Time (URT)

\begin{tabular}{llllll}
\hline & $\begin{array}{l}\text { Original } \\
\text { Sample (O) }\end{array}$ & $\begin{array}{l}\text { Sample } \\
\text { Mean } \\
(\mathrm{M})\end{array}$ & $\begin{array}{l}\text { Standard } \\
\text { Deviation }\end{array}$ & $\begin{array}{l}\text { Ttatistic } \\
\text { (IO/STDEV) }\end{array}$ & $\begin{array}{l}\text { P } \\
\text { Values }\end{array}$ \\
\hline URT <-- Dysfunctional Audit Behavior (DAB) & 0.893 & 0.890 & 0.025 & 35.51 & 0.000 \\
\hline URT 01 <-- Under-reporting of Time (URT) & 0.713 & 0.697 & 0.073 & 9.811 & 0.000 \\
\hline URT 02 <-- Under-reporting of Time (URT) & 0.695 & 0.688 & 0.066 & 10.555 & 0.000 \\
\hline URT 03 <-- Under-reporting of Time (URT) & 0.744 & 0.742 & 0.039 & 19.295 & 0.000 \\
\hline URT 04<-- Under-reporting of Time (URT) & 0.802 & 0.798 & 0.039 & 20.401 & 0.000 \\
\hline URT 05<-- Under-reporting of Time (URT) & 0.777 & 0.775 & 0.043 & 17.866 & 0.000 \\
\hline URT 06 <-- Under-reporting of Time (URT) & 0.726 & 0.726 & 0.047 & 15.338 & 0.000 \\
\hline
\end{tabular}

Based on the first order confirmatory analysis, the loading factors of all attributes manifested under-reporting of time (URT). The higher the loading factor (original sample and sample mean), the better the attribute in reflecting/manifesting the under-reporting of time (URT). The $\mathrm{t}_{\text {-statistics }}$ were higher than 1.96 and the $\mathrm{p}_{\text {-values }}$ were lower than 0.05 so all attributes were manifested the factor significantly.

\subsubsection{The Attributes of Premature Sign-Off (PMSO)}

The loading factor (original sample and sample mean) indicates the degree of the attributes in manifesting/reflecting the factors. The $\mathrm{t}_{\text {statistic }}$ or $\mathrm{t}_{\text {-value }}$ of the attributes of premature sign-off (PMSO) are shown in the table.

Table 4. The manifestation of attributes of Premature Sign-off (PMSO)

\begin{tabular}{|c|c|c|c|c|c|}
\hline & $\begin{array}{l}\text { Original } \\
\text { Sample }(O)\end{array}$ & $\begin{array}{l}\text { Sample } \\
\text { Mean } \\
\text { (M) }\end{array}$ & $\begin{array}{l}\text { Standard } \\
\text { Deviation }\end{array}$ & $\begin{array}{l}\text { T Statistic } \\
(\mathrm{IO} / \mathrm{STDEV})\end{array}$ & $\begin{array}{l}\mathrm{P} \\
\text { Values }\end{array}$ \\
\hline $\begin{array}{llll}\text { PMSO }<- & \text { Dysfunctional Audit Behavior } \\
\text { (DAB) } & & & \\
\end{array}$ & 0.924 & 0.923 & 0.015 & 63.012 & 0.000 \\
\hline PMSO $01<-$ Premature Sign-off (PMSO) & 0.752 & 0.749 & 0.054 & 13.959 & 0.000 \\
\hline PMSO $02<-$ > Premature Sign-off (PMSO) & 0.710 & 0.705 & 0.073 & 9.725 & 0.000 \\
\hline PMSO $03<-$ Premature Sign-off (PMSO) & 0.721 & 0.716 & 0.055 & 13.013 & 0.000 \\
\hline PMSO $04<-$ Premature Sign-off (PMSO) & 0.760 & 0.758 & 0.044 & 17.343 & 0.000 \\
\hline PMSO $05<-$ Premature Sign-off (PMSO) & 0.705 & 0.706 & 0.054 & 13.169 & 0.000 \\
\hline PMSO $06<-$ Premature Sign-off (PMSO) & 0.747 & 0.744 & 0.047 & 16.021 & 0.000 \\
\hline PMSO 07 <-- Premature Sign-off (PMSO) & 0.517 & 0.518 & 0.081 & 6.352 & 0.000 \\
\hline PMSO $08<-$ Premature Sign-off (PMSO) & 0.690 & 0.686 & 0.074 & 9.303 & 0.000 \\
\hline PMSO $09<-$ Premature Sign-off (PMSO) & 0.704 & 0.701 & 0.056 & 12.645 & 0.000 \\
\hline PMSO $10<-$ Premature Sign-off (PMSO) & 0.746 & 0.745 & 0.044 & 17.120 & 0.000 \\
\hline
\end{tabular}

Based on the first order confirmatory analysis, the loading factors of all attributes manifested premature sign-off (PMSO). The higher the loading factor (original sample and sample mean), the better the attribute in reflecting/manifesting the premature sign-off (PMSO). The $\mathrm{t}_{\text {-statistics }}$ were higher than 1.96 and the $\mathrm{p}_{\text {-values }}$ were lower than 0.05 , so all attributes were manifested the factor significantly.

\subsubsection{The Attributes of Time-Budget Pressure (TBP)}

The loading factor (original sample and sample mean) indicates the degree of the attributes in manifesting/reflecting the factors. The $\mathrm{t}_{\text {-statistic }}$ or $\mathrm{t}_{\text {-value }}$ of the attributes of time-budget pressure(TBP) are shown in table 5. 
Based on the first order confirmatory analysis, the loading factors of all attributes manifested time-budget pressure (TBP). The higher the loading factor (original sample and sample mean), the better the attribute in reflecting/manifesting the time-budget pressure (TBP). The $\mathrm{t}_{\text {-statistics }}$ were higher than 1.96 and the $\mathrm{p}_{\text {-values }}$ were lower than 0.05 so all attributes were manifested the factor significantly.

Table 5. The manifestation of attributes of Time-Budget Pressure (TBP)

\begin{tabular}{llllll}
\hline & $\begin{array}{l}\text { Original } \\
\text { Sample }(\mathrm{O})\end{array}$ & $\begin{array}{l}\text { Sample } \\
\text { Mean } \\
(\mathrm{M})\end{array}$ & $\begin{array}{l}\text { Standard } \\
\text { Deviation }\end{array}$ & $\begin{array}{l}\mathrm{T} \text { Statistic } \\
(\text { IO/STDEV) }\end{array}$ & $\begin{array}{l}\mathrm{P} \\
\text { Values }\end{array}$ \\
\hline TBP <-- Dysfunctional Audit Behavior (DAB) & 0.875 & 0.874 & 0.026 & 33.789 & 0.000 \\
\hline TBP 01 <-- Time Budget Pressure (TBP) & 0.817 & 0.815 & 0.041 & 19.904 & 0.000 \\
\hline TBP 02 <-- Time Budget Pressure (TBP) & 0.826 & 0.826 & 0.034 & 24.076 & 0.000 \\
\hline TBP 03 <-- Time Budget Pressure (TBP) & 0.836 & 0.835 & 0.032 & 25.782 & 0.000 \\
\hline TBP 04 <-- Time Budget Pressure (TBP) & 0.788 & 0.784 & 0.040 & 19.626 & 0.000 \\
\hline
\end{tabular}

\subsubsection{The Attributes of Task Complexity (TC)}

The loading factor (original sample and sample mean) indicates the degree of the attributes in manifesting/reflecting the factors. The $\mathrm{t}_{\text {-statistic }}$ or $\mathrm{t}_{\text {-value }}$ of the attributes of task complexity (TC) are shown in the table.

Table 6. The manifestation of attributes of Task Complexity (TC)

\begin{tabular}{llllll}
\hline & $\begin{array}{l}\text { Original } \\
\text { Sample (O) }\end{array}$ & $\begin{array}{l}\text { Sample } \\
\text { Mean } \\
(\mathrm{M})\end{array}$ & $\begin{array}{l}\text { Standard } \\
\text { Deviation }\end{array}$ & $\begin{array}{l}\text { T Statistic } \\
\text { (IO/STDEV) }\end{array}$ & $\begin{array}{l}\text { Palues } \\
\text { Valon }\end{array}$ \\
\hline TC <-- Dysfunctional Audit Behavior (DAB) & 0.886 & 0.885 & 0.025 & 35.851 & 0.000 \\
\hline TC 01 <-- Task Complexity (TC) & 0.849 & 0.848 & 0.041 & 20.860 & 0.000 \\
\hline TC 02 <-- Task Complexity (TC) & 0.873 & 0.872 & 0.027 & 32.921 & 0.000 \\
\hline TC 03 <-- Task Complexity (TC) & 0.840 & 0.842 & 0.034 & 24.632 & 0.000 \\
\hline TC 04 <-- Task Complexity (TC) & 0.805 & 0.805 & 0.039 & 20.730 & 0.000 \\
\hline TC 05 <-- Task Complexity (TC) & 0.578 & 0.574 & 0.076 & 7.564 & 0.000 \\
\hline
\end{tabular}

Based on the first order confirmatory analysis, the loading factors of all attributes manifested task complexity (TC). The higher the loading factor (original sample and sample mean), the better the attribute in reflecting/manifesting the task complexity (TC). The $\mathrm{t}_{\text {-statistics }}$ of all attributes were higher than 1.96 and the $\mathrm{p}_{\text {-values }}$ were lower than 0.05 so all attributes were manifest the task complexity (TC) significantly.

\subsection{The Hypotheses Testing - Second Order Confirmatory Factor Analysis}

To test the hypothesis, we can see the inner loading factors and significant level $\left(\mathrm{t}_{\text {-statistic }}\right)$ and $\mathrm{p}_{\text {-values. }}$ The higher the loading factor, the bigger the manifestation/reflection of one construct to others. The effect of the construct is statistically significant if the $\mathrm{t}_{\text {-statistic }}$ is higher than 1.96 and $\mathrm{p}_{\text {-values }}$ lower than 0.05 at the confidence interval of $95 \%$. The results of hypotheses testing using second order component factor analysis were shown in the table below. 
Table 7. The result of hypotheses testing

\begin{tabular}{|c|c|c|c|c|c|c|}
\hline & $\begin{array}{l}\text { Original } \\
\text { Sample }(\mathrm{O})\end{array}$ & $\begin{array}{l}\text { Sample } \\
\text { Mean } \\
(\mathrm{M})\end{array}$ & $\begin{array}{l}\text { Standard } \\
\text { Deviatio } \\
\mathrm{n}\end{array}$ & $\begin{array}{l}\text { T Statistic } \\
(\mathrm{IO} / \mathrm{STDEV} \\
\text { ) }\end{array}$ & $\begin{array}{l}\mathrm{P} \\
\text { Values }\end{array}$ & $\begin{array}{l}\text { Hypothese } \\
\text { s Testing }\end{array}$ \\
\hline $\begin{array}{l}\text { Dysfunctional Audit Behavior } \\
\text { (DAB) --> Under-reporting of Time } \\
\text { (URT) }\end{array}$ & 0.905 & 0.905 & 0.018 & 51.250 & 0.000 & $\begin{array}{l}\text { Positive } \\
\text { Significant }\end{array}$ \\
\hline $\begin{array}{lcc}\text { Dysfunctional } & \text { Audit } & \text { Behavior } \\
\text { (DAB) --> } & \text { Premature } & \text { Sign-off } \\
\text { (PMSO) } & & \end{array}$ & 0.931 & 0.930 & 0.012 & 75.115 & 0.000 & $\begin{array}{l}\text { Positive } \\
\text { Significant }\end{array}$ \\
\hline $\begin{array}{l}\text { Dysfunctional Audit Behavior } \\
\text { (DAB) --> Time-Budget Pressure } \\
\text { (TBP) }\end{array}$ & 0.878 & 0.879 & 0.025 & 35.396 & 0.000 & $\begin{array}{l}\text { Positive } \\
\text { Significant }\end{array}$ \\
\hline $\begin{array}{l}\text { Dysfunctional Audit Behavior } \\
\text { (DAB) --> Task Complexity (TC) }\end{array}$ & 0.887 & 0.888 & 0.024 & 37.274 & 0.000 & $\begin{array}{l}\text { Positive } \\
\text { Significant }\end{array}$ \\
\hline
\end{tabular}

The result of the second-order confirmatory factor analysis in PLS show that the loading factor (manifestation) of dysfunctional audit behavior (DAB) reflected by under-reporting of time (URT) was 0.905 and $\mathrm{t}_{\text {-statistic }}$ was 51.250 and

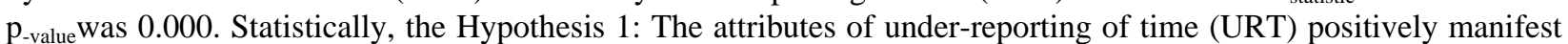
the dysfunctional audit behavior (DAB) was supported. The higher the incidence of under-reporting of time (URT) the higher the probability of the incidence of dysfunctional audit behavior (DAB) is.

The loading factor (manifestation) of dysfunctional audit behavior (DAB) reflected by premature sign-off (PMSO)

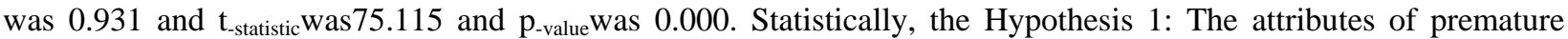
sign-off (PMSO) positively manifest the dysfunctional audit behavior (DAB) was supported. The higher the incidence of premature sign-off (PMSO) the higher the probability of the incidence of dysfunctional audit behavior $(\mathrm{DAB})$ is.

The loading factor (manifestation) of dysfunctional audit behavior (DAB) reflected by time-budget pressure (TBP) was 0.878 and $t_{\text {-statistic }}$ was 35.396 and $\mathrm{p}_{\text {-value }}$ was 0.000. Statistically, the Hypothesis 1: The attributes of time-budget pressure (TBP) positively manifest the dysfunctional audit behavior (DAB) was supported. The higher the incidence of time-budget pressure (TBP) the higher the probability of the incidence of dysfunctional audit behavior (DAB).

The loading factor (manifestation) of dysfunctional audit behavior (DAB) reflected by task complexity (TC) was 0.887 and $\mathrm{t}_{\text {-statistic }}$ was 37.274 and $\mathrm{p}_{\text {-value }}$ was 0.000 . Statistically, the Hypothesis 1 : The attributes of task complexity (TC) positively manifest the dysfunctional audit behavior (DAB) was supported. The higher the incidence of task complexity (TC) the higher the probability of the incidence of dysfunctional audit behavior (DAB) is.

\section{Conclusion}

Based on the research finding, all of the attributes of under-reporting of time (URT); premature sign-off (PMSO); time-budget pressure (TBP); and task complexity (TC) manifested the dysfunctional audit behavior (DAB). In another word, under-reporting of time (URT); premature sign-off (PMSO); time-budget pressure (TBP); and task complexity (TC) were the predictor of the dysfunctional audit behavior (DAB). The research finding also confirms that the task complexity (TC), can be used as a predictor of dysfunctional audit behavior (DAB) as proposed. Task complexity stressed the auditor and has an indirect effect on dysfunctional audit behavior. In term of audit quality, under-reporting of time (URT); premature sign-off (PMSO); time-budget pressure (TBP); and task complexity (TC) were a set of actions that reduce the audit quality.

This result was confirmed that the underreporting threatens audit quality by perpetuating tight budgets, which may cause auditors to perform inferior procedures (Kelley and Margheim 1990). Underreporting, or reporting fewer hours than actually worked, is a prevalent behavior among auditors at all levels (Taylor, et.al 2012). Auditors often underreport their hours in response to both manager pressures and the desire to appear more efficient (Agoglia, et.al 2015).

Underreporting leads to several negative consequences that impact audit firms, auditors, audit quality, and measures of audit quality. First, underreporting perpetuates artificially tight audit budgets. Auditors use underreported audit 
hours to create future budgets that are then tighter than they would be with actual hours as an input. To make matters worse, these tight budgets then impact next year's reported audit hours, which perpetuate the cycle. Prior studies document that tight budgets reduce audit quality because auditors lack time to gather sufficient evidence, leading to the omission of significant audit findings and documentation of procedures that were never performed (Otley and Pierce 1996; Donnelly et al. 2003; Coram, et.al 2004).

Auditors face many pressures or incentives to underreport. For example, auditors frequently encounter tight budgets, which exert pressure to be unrealistically efficient (Margheim and Pany 1986; Kelley and Margheim 1990). Also, auditors can face explicit or implicit pressure from their superiors to underreport when they are not meeting the budget (Lightner et al. 1982; Taylor et al. 2012; Agoglia et al. 2015). Auditors can reap benefits from underreporting such as the ability to appear more valuable or efficient than their peers, which could result in better performance evaluations and promotion opportunities (Sweeney and Pierce 2006). All of these incentives lead to the pervasive underreporting that exists in the audit profession.

There are several limitations that should be considered when evaluating the results of this study. The attributes, indicators or constructs investigated in the study are not meant to be complete or exhaustive; there may be other variables that manifest underreporting of time, premature sign-off, time-budget pressure, and task complexity, which were not included. Finally, the study looks only at the antecedents of underreporting, premature sign-off, time-budget pressure, and task complexity in manifesting dysfunctional audit behavior but not the consequences.

\section{References}

Abbott, L. J., Daugherty, B., Parker, S., \& Peters, G. F. (2016). Internal Audit Quality and Financial Reporting Quality: The Joint Importance of Independence and Competence. Journal of Accounting Research, 54(1), 3-40. https://doi.org/10.1111/1475-679X.12099

Adnan, N. L. B., Muhammad Jamil, C. Z., \& Mohd Nor, N. A. (2012). Ethical antecedents of dysfunctional behavior in performance measurement and control system. Asian Social Science, 9(1), 29-41. https://doi.org/10.5539/ass.v9n1p29

Agoglia, C. P., Hatfield, R. C., \& Lambert, T. A. (2015). Audit team time reporting: An agency theory perspective. Accounting, Organizations and Society, 44, 1-14. https://doi.org/10.1016/j.aos.2015.03.005

Alderman, C. W., \& Deitrick, J. W. (1982). Auditors' perceptions of time budget pressures and premature sign-offs: A replication and extension. Auditing: A Journal of Practice \& Theory, 1(2), 54-68.

Al-Shbiel, S. O. (2016). An Examination of the Factors Influences on Unethical Behaviour among Jordanian external auditors: Job Satisfaction as a mediator. International Journal of Academic Research in Accounting, Finance and Management Sciences, 6(3), 285-296. https://doi.org/10.6007/IJARAFMS/v6-i3/2276

Amrizal. (2014). Analisis Kritis Pelanggaran Kode Etik Profesi Akuntan Publik di Indonesia. Jurnal Liquidity, 3(1), 36-43. https://doi.org/10.32546/lq.v3i1.103

Amroabadi, M. S., Khanagha, J. B., \& Naderibeni, M. (2014). Professional Commitment on Dysfunctional Audit Behaviour In audit organizations of Isfahan Public Accountancy. Interdisciplinary Journal of Contemporary Research in Business, 5(9), 275-283.

Anugerah, R., Anita, R., Sari, R., Abdillah, M., \& Iskandar, T. (2016, December). The Analysis of Reduced Audit Quality Behavior: The Intervening Role of Turnover Intention. International Journal of Economics and Management, 10, 341-353. https://doi.org/10.18178/joebm.2016.4.5.416

Ardelean, A. (2013). Auditors' Ethics and their Impact on Public Trust. Procedia-Social and Behavioral Sciences, 92, 55-60. https://doi.org/10.1016/j.sbspro.2013.08.637

Armitage, J. L., \& Moriarity, S. R. (2016). An Examination of AICPA Disciplinary Actions: 1980-2014. Current Issues in Auditing, 10(2), A1-A13. https://doi.org/10.2308/ciia-51466

Asare, S. K., \& McDaniel, L. S. (1996). The effect of familiarity with the prepare and task complexity on the effectiveness of the audit review process. The Accounting Review, 71, 139-160.

Baldacchino, P. J., Tabone, N., Agius, J., \& Bezzina, F. (2016). Organizational Culture, Personnel Characteristics and Dysfunctional Audit Behavior. The IUP Journal of Accounting Research \& Audit Practices, XV(3).

Beekes, W. A., Otley, D., \& Ururuka, V. (2014, July). Factors influencing Quality Threatening Behaviour in a Big Four Accounting Firm. Lancaster University Management School, 44, 1-39. https://doi.org/10.2139/ssrn.2462456 
Bonner, S. E. (1994). A model of the effects of audit task complexity. Accounting, Organizations and Society, 19(3), 213-234. https://doi.org/10.1016/0361-3682(94)90033-7

Cook, E., \& Kelley, T. (1988, July). Auditor Stress and Time Budgets. The CPA Journal, 83-86.

Coram, P. J., \& Robinson, M. J. (2003). Professionalism and performance incentives in accounting firms. Accounting Horizons, 31(1), 103-123. https://doi.org/10.2308/acch-51636

Donnelly, D. P., Quirin, J. J., \& O’Bryan, D. (2003). Auditor Acceptance of Dysfunctional Audit Behavior: An Explanatory Model Using Auditors Personal Characteristics. Behavioral Research in Accounting. https://doi.org/10.2308/bria.2003.15.1.87

Gundry, C. L. (2006). Dysfunctional Behaviour in Modern Audit Environment: The Effect of Time Budget Pressure and Auditors' Personality Type on Reduced Audit Quality Practices. Bachelor of Commerce Dissertation, University of Otago, New Zealand.

Halim, A., Sutrisno, T., \& Achsin, M. (2014). Effect of Competence and Auditor Independence on Audit Quality with Audit Time Budget and Professional Commitment as a Moderation Variable. Internaiional Journal of Business and Management Invention, 3(6), 64-74.

Jiambalvo, J., \& Pratt, J. (1982). Task complexity and leadership effectiveness in CPA firms. The Accounting Review, 57(4), 734-750.

Kelley, T., \& Margheim, L. (1990). The impact of time-budget pressure, personality, and leadership variables on dysfunctional auditor behavior. Auditing: A Journal of Practice \& Theory, 9, Spring, 21-42.

Khan, S., Panatik, S. A. B., \& Saat, M. B. (2015). Dysfunctional audit behaviors: An exploratory study in Pakistan. Research Journal of Applied Sciences, Engineering and Technology, 9(9), 778-785. https://doi.org/10.19026/rjaset.9.2624

Khan, S., Panatik, S. A., Saat, M. M., \& Perveeen, H. (2013). Auditors' behavioral intention towards dysfunctional audit behavior applying theory of reasoned action. Jurnal Teknologi (Sciences and Engineering), 64(3), 153-158. https://doi.org/10.11113/jt.v64.2287

Kustinah, S. (2013). The Influence of Dysfunctional Behavior and Individual Culture on Audit Quality. International Journal of Scientific \& Technology Research, 2(5), 118-125.

Lightner, S. M., Adams, S. J., \& Lightner, K. M. (1982). The influence of Situational, Ethical and Expectancy Theory Variables on Accountants' Underreporting Behavior. Auditing: A Journal of Practice \& Theory, 2(1), 1-12.

Liu, P., \& Li, Z. (2012). Task complexity: A review and conceptualization framework. International Journal of Industrial Ergonomics, 42(6), 553-568. https://doi.org/10.1016/j.ergon.2012.09.001

Malone, C. F., \& Roberts, R. W. (1996). Factors associated with the incidence of reduced audit quality behaviors. Auditing, 15(2), 49.

Margheim, L., \& Pany, K. (1986). Quality-Control, Premature Signoff, and Underreporting of Time-Some Empirical-Findings. Auditing-A Journal of Practice \& Theory, 5(2), 50-63.

Mohd-Sanusi, Z., \& Mohd-Iskandar, T. (2007). Audit judgment performance: assessing the effect of performance incentives, effort and task complexity. Managerial Auditing Journal, 22(1), 34-52. https://doi.org/10.1108/02686900710715639

Nazli, M. N., Smith, M., \& Ismail, Z. (2009). Auditors' Perception of Time Budget Pressure and Reduced Audit Quality Practices: A Preliminary Study From Malaysian Context, Research Paper. Edit Cowan University.

Nehme, R., Mutawa, A. Al., \& Jizi, M. (2016). Dysfunctional Behavior of External Auditors the Collision of Time Budget and Time Deadline Evidence from a Developing Country. Journal of Developing Areas, 50(1), 373-388. https://doi.org/10.1353/jda.2016.0003

Nuijten, A., van Twist, M., \& van der Steen, M. (2015). Auditing Interactive Complexity: Challenges for the Internal Audit Profession. International Journal of Auditing, 19(3), 195-205. https://doi.org/10.1111/ijau.12049

Otley, D. T., \& Dias, F. J. (1982). Accounting aggregation and decision-making performance: An experimental investigation. Journal of Accounting Research, 171-188. https://doi.org/10.2307/2490769 
Otley, D. T., \& Pierce, B. J. (1995). The control problem in public accounting firms: An empirical study of the impact of leadership style. Accounting, Organizations and Society, 20(5), 405-420. https://doi.org/10.1016/0361-3682(95)00003-R

Otley, D. T., \& Pierce, B. J. (1996). Auditor time budget pressure: consequences and antecedents. Accounting, Auditing \& Accountability Journal, 9(1), 31-58. https://doi.org/10.1108/09513579610109969

Paino, H., Ismail, Z., \& Smith, M. (2010). Dysfunctional audit behaviour: an exploratory study in Malaysia. Asian Review of Accounting, 18(2), 162-173. https://doi.org/10.1108/13217341011059417

Paino, H., Ismail, Z., \& Smith, M. (2014). Modelling Dysfunctional Behaviour: Individual Factors and Ethical Financial Decision. Procedia - Social and Behavioral Sciences, 145, 116-128. https://doi.org/10.1016/j.sbspro.2014.06.018

Paino, H., Smith, M., \& Ismail, Z. (2012b). Auditor acceptance of dysfunctional behaviour: An explanatory model using individual factors. Journal of Applied Accounting Research, 13(1), 37-55. https://doi.org/10.1108/09675421211231907

Paino, H., Thani, A., \& Iskandar, S. (2011). Attitudes toward dysfunctional audit behaviour: The effect of budget emphasis, leadership behaviour, and effectiveness of audit review. 2011 IEEE Symposium on Industrial Electronics and Applications (pp. 574-578). https://doi.org/10.1109/ISIEA.2011.6108778

Paino, T., \& Idris. (2012a). Organizational and professional commitment on dysfunctional audit behaviour. African Journal of Business Management, 6(4), 94-105. https://doi.org/10.5897/AJBM11.1974

Pickerd, J. S., Summers, S. L., \& Wood, D. A. (2015). An examination of how entry-level staff auditors respond to tone at the top vis-a'-vis tone at the bottom. Behavioral Research in Accounting, 27(1), 79-98. https://doi.org/10.2308/bria-50918

Ponemon, L. A. (1992). Auditor Underreporting of Time and Moral Reasoning: An Experimental Lab Study. Contemporary Accounting Research, 9(1), 171-189. https://doi.org/10.1111/j.1911-3846.1992.tb00875.x

Pruijssers, J., Van Oosterhout, H., \& Heugens, P. (2013). Organizational antecedents of dysfunctional auditor behaviors: the mitigating role of audit firm governance. Working Paper. https://doi.org/10.2139/ssrn.2251828

Rhode, J. G. (1977). Survey on the influence of selected aspects of the auditor's work environment on professional performance of certified public accountants. Issued as the Independent Auditor's Work Environment: A Survey. New York, NY: AICPA.

Soobaroyen, T., \& Chengabroyan, C. (2006). Auditors' Perceptions of Time Budget Pressure, Premature Sign Offs and Under-Reporting of Chargeable Time: Evidence from a Developing Country. International Journal of Auditing, 10(3), 201-218. https://doi.org/10.1111/j.1099-1123.2006.0350.x

Svanström, T. (2016). Time Pressure, Training Activities and Dysfunctional Auditor Behaviour: Evidence from Small Audit Firms. International Journal of Auditing, 20(1), 42-51. https://doi.org/10.1111/ijau.12054

Sweeney, B., \& Pierce, B. (2006). Good hours, bad hours and auditors' defence mechanisms in audit firms. Accounting, Auditing \& Accountability Journal, 19(6), 858-892. https://doi.org/10.1108/09513570610709908

Sweeney, B., \& Pierce, B. (2015). Audit Quality Threatening Behaviours: Perceptions of Auditees. Accounting, Finance and Governance Review, 22(2), 47-76.

Syam, M. A., Ghozali, I., Achmad, T., \& Faisal. (2017). The impact of authentic leadership, corporate ethical values, employee incentives and workload/task complexity on dysfunctional auditor behavior. International Journal of Economic Research, 14(9), 11-28.

Taylor, E. Z., Curtis, M. B., \& Chui, L. (2012, June). Staff Auditors' Observations of Questionable Peer Behavior: The view from the other side. The CPA Journal, 66-71.

Yuen, D. C. Y., Law, P. K. F., Lu, C., \& Qi Guan, J. (2013). Dysfunctional auditing behaviour: empirical evidence on auditors' behaviour in Macau. International Journal of Accounting \& Information Management, 21(3), 209-226. https://doi.org/10.1108/IJAIM-12-2012-0075 